\title{
Scholars and Literati at the Royal College in Paris (1530-1800)
}

\author{
David de la Croix
}

IRES/LIDAM, UCLouvain

This note is a summary description of the set of scholars and literati taught at the Royal College in Paris, from its inception in 1530 to the eve of the Industrial Revolution (1800).

\section{The College}

The Royal College of Paris is one of the very few French institutions of higher learning to have been continuously in operation, from its establishment in the sixteenth century until now. It was not disrupted by the Revolution, and the "Collège de France" of 2020 is the proud continuation of this Renaissance School. It was established by King Francis I of France, modeled after the Collegium Trilingue in the University of Louvain (now Belgium). Of humanist inspiration, the school was established as an alternative to the University of Paris (Sorbonne) to promote disciplines which were not taught at the university, such as Hebrew, Ancient Greek and Sciences (Compère 2002). At the Royal College, humanism triumphed without the university, in spite of it, against it (Guénée 1981). In the seventeenth century, lectures did not embrace unanimously the breakthroughs of the Scientific Revolution. For example, the College accommodated both supporters and opponents of Cartesianism (Applebaum 2003).

\section{SOURCES}

The list of professors can be found on the website of the Collège de France (Collège de France 2007). Additional biographical information was collected from the biographical dictionary by Michaud (1811).

\section{SOME STATISTICS}

Some statistics on the 263 professors are presented in Table 1. A majority of them are quite well known - for example, $62 \%$ have a Wikipedia page. $73.4 \%$ of them have left a footprint in the libraries today. The period with the highest number of obscure scholars is $1618-1685$ as we can from the $\%$ of persons with known birth year and place. The column "median distance birth-institution" shows that the institution became more and more Parisian as time passed.

\section{FIELDS}

Figure 1 shows the relative importance of fields, broadly defined. The distribution of fields highlights the specificity of the Royal College compared to a standard university. Law and Theology have minimal weight, while Humanities, Medicine and Sciences take the lion's share. Mathematics are present from the beginning. The label "Humanities" covers a variety of unusual Chairs, such as that of Arabic created in 1587, and that of Syriac (1692). 


\begin{tabular}{|c|c|c|c|c|c|c|}
\hline \multicolumn{2}{|c|}{ Period } & \multirow{2}{*}{$\begin{array}{l}\text { nb. } \\
\text { obs }\end{array}$} & \multirow{2}{*}{$\begin{array}{l}\% \text { birth year } \\
\text { known }\end{array}$} & \multirow{2}{*}{$\begin{array}{l}\text { mean age } \\
\text { at appoint. }\end{array}$} & \multirow{2}{*}{$\begin{array}{l}\text { mean age } \\
\text { at death }\end{array}$} & \multirow{2}{*}{$\begin{array}{l}\text { exp. age } \\
\text { at death }\end{array}$} \\
\hline Start & End & & & & & \\
\hline 1527 & 1617 & 92 & 63.0 & 40.4 & 63.7 & 60.6 \\
\hline 1618 & 1685 & 68 & 52.9 & 44.4 & 66.5 & 48.8 \\
\hline 1686 & 1733 & 43 & 79.1 & 43.7 & 69.5 & 69.9 \\
\hline 1734 & 1800 & 60 & 90.0 & 42.3 & 71.5 & 71.8 \\
\hline \multirow{2}{*}{1000} & 1800 & 263 & $69 . \overline{2}$ & 42.4 & $6 \overline{7} . \overline{7}$ & 64.9 \\
\hline & & & $\begin{array}{c}\text { \% birth place } \\
\text { known }\end{array}$ & $\begin{array}{l}\text { median distance } \\
\text { birth-institution }\end{array}$ & $\begin{array}{c}\% \text { with } \\
\text { Wikipedia }\end{array}$ & $\begin{array}{c}\% \text { with } \\
\text { Worldcat }\end{array}$ \\
\hline 1527 & 1617 & & 65.2 & 176 & 62.0 & 66.3 \\
\hline 1618 & 1685 & & 52.9 & 216 & 44.1 & 61.8 \\
\hline 1686 & 1733 & & 79.1 & 153 & 69.8 & 86.0 \\
\hline 1734 & 1800 & & 78.3 & 78 & 76.7 & 88.3 \\
\hline 1000 & 1800 & & $\overline{6} \overline{7} . \overline{3}$ & $\overline{174}$ & $\overline{6} \overline{2} . \overline{0}$ & 73.4 \\
\hline
\end{tabular}

Table 1: Summary statistics by period

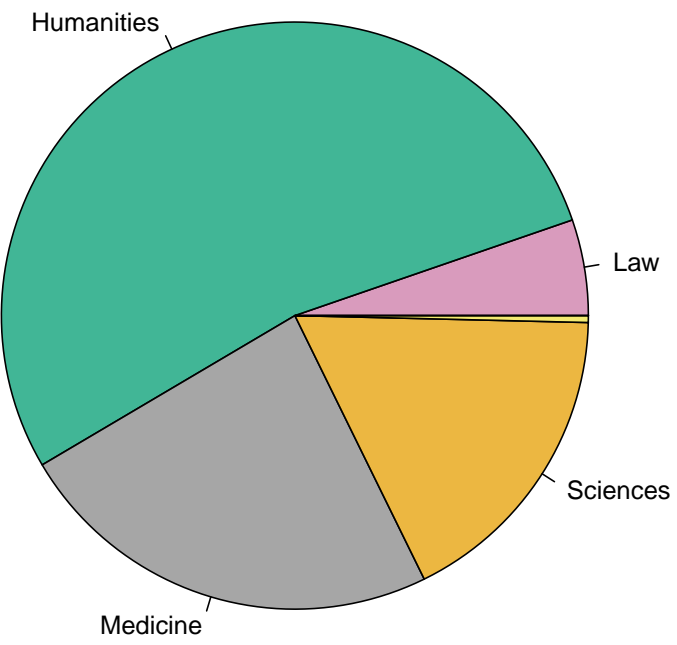

Figure 1: Broad fields at the Royal College

\section{Place of Birth}

Figure 2 is a plot of the places of birth of all the scholars of the Royal College, and shows the very French character of this College. It is surprising that it did not attract more talents from abroad, in particular given the very high quality of the institution. Perhaps, the fact that all teaching was in French (Guénée 1981) served as a barrier to entry.

\section{HUMAN CAPITAL OF SCHOLARS AND LITERATI}

For each person in the database we compute a heuristic human capital index, identified by combining information from Worldcat and Wikipedia using a principal component analysis. We also compute the notability of the university at each date by averaging the human capital of the scholars active at the Royal College 25 years before that date. Details are given in the Appendix. Figure 3 shows the names of all the scholars with a positive human capital index. The orange line plots the notability of the university. The vertical green lines (rug plot) show the distribution of all scholars, including 


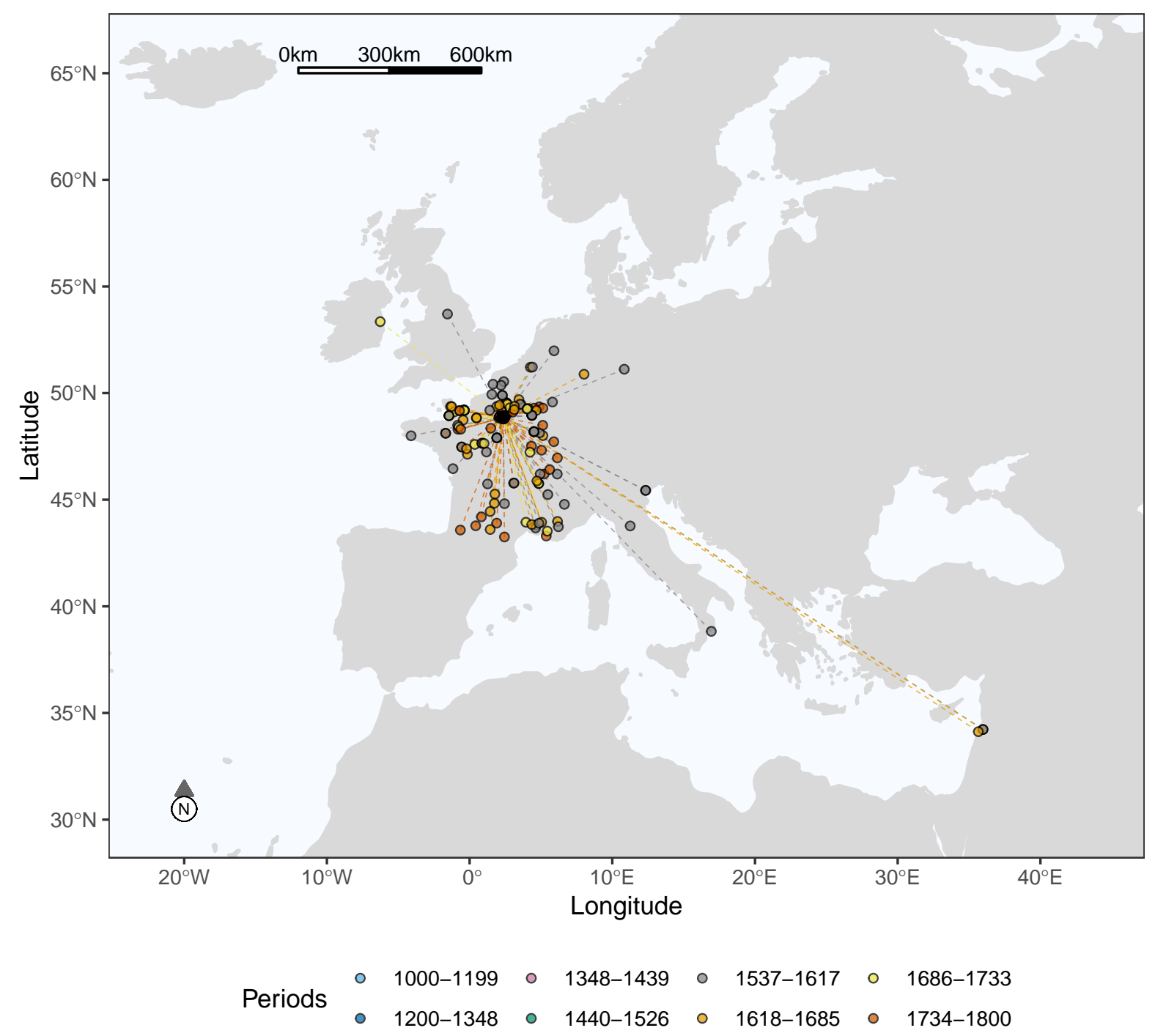

Figure 2: Place of birth of the scholars and literati at the Royal College

the obscure ones.

The picture painted by Figure 3 is one of an excellent institution of higher learning, with a wealth of excellent scholars. This is true for the whole time span considered, without any period of marked decline. Two peaks in notability appear: One shortly after the creation of the College, and the other at the beginning of the eighteenth century.

\section{TOP 5 PROFESSORS}

We provide here a brief overview of the five professors with the highest human capital index.

Isaac Casaubon (Geneva 1559 - London 1614), was born to two Huguenot refugees and spent his life at finding his place as a French Protestant in a changing world. First professor in Geneva, he moved to the University of Montpellier, when it was still permitted to hire Calvinist professors, and then to the Royal College, were he taught Greek for ten years. He then moved to England, where he published and commented classical authors.

Pierre Gassendi (Champtercier 1592 - Paris 1655), was a Catholic priest, astronomer, and mathematician. Initially professor of theology at the University of Aix-en-Provence, he was torn between the traditional Aristotelian philosophy and the discoveries of Galileo and Kepler. 


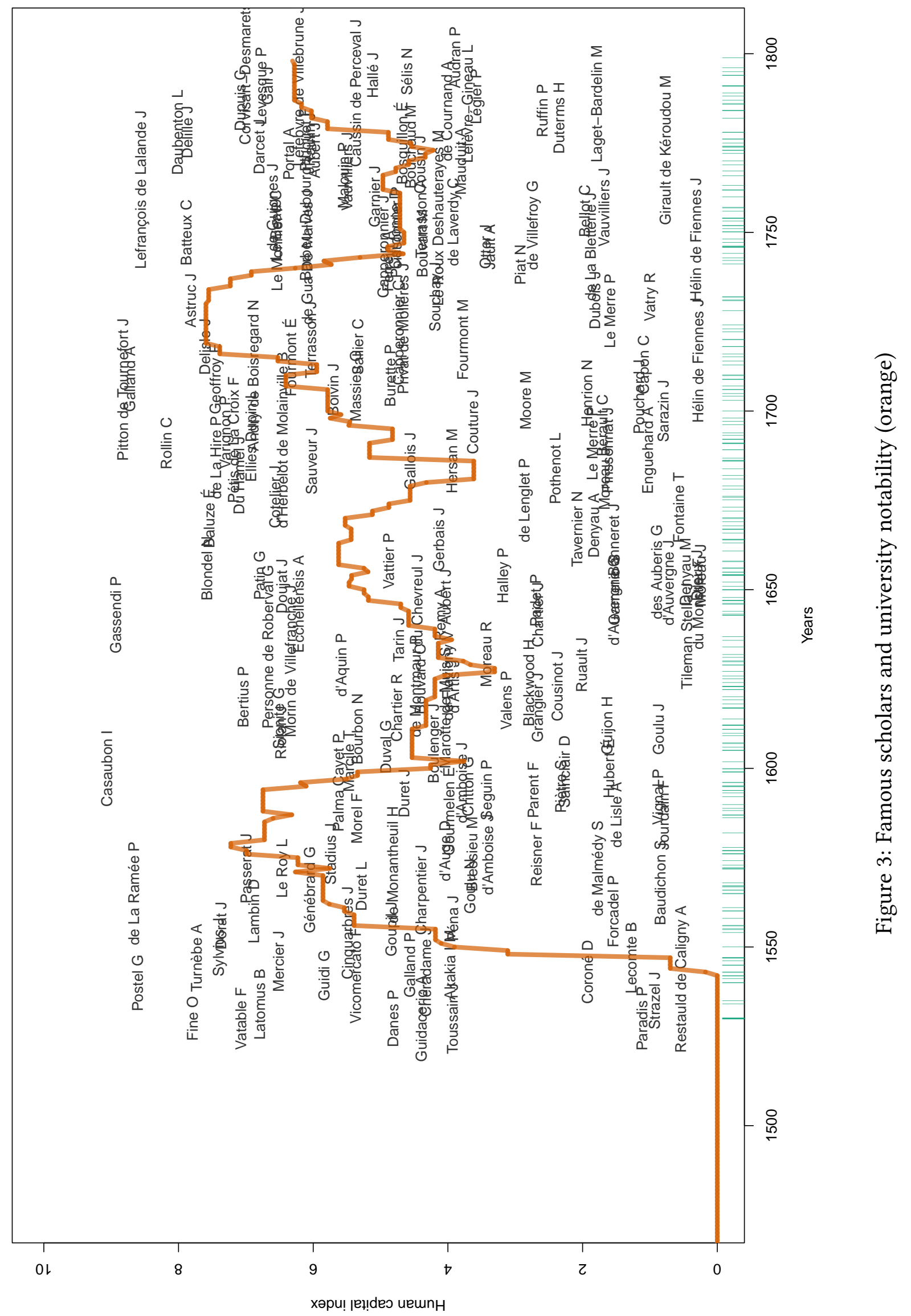


At the informal "Mersenne" Academy, he exchanged ideas with Descartes and stated explicitly his mind-body model. He was hired to the chair of mathematics at the Royal College. He was a forerunner in several scientific discoveries, and a crater on the moon is named after him.

Joseph Pitton de Tournefort (Aix-en-Provence 1656 - Paris 1708) was a botanist. He was appointed to the best scientific institutions in Paris: the Académie des Sciences, the Jardin des Plantes, and the Royal College where he taught medicine and botany for three years. He is credited as being the first to make a clear definition of the concept of genus for plants.

Antoine Galland (Rollot 1646 - Caen 1715) was an orientalist and archaeologist, most famous as the first European translator (from Arabic into French) of One Thousand and One Nights. In 1709 he was appointed to the chair of Arabic at the Royal College, a position he occupied until his death. He was also a member of the "Académie des arts et belles lettres" in Caen (Normandy) and of the Parisian "Académie des inscriptions et des belles lettres".

Pierre de La Ramée (Cuts 1515 - Paris 1572) started his academic career at the University of Paris, where he taught against Aristotelian principles. In 1551 he was appointed to teach philosophy at the Royal College. After converting to Protestantism, he had to flee Paris. We find him teaching in Heildelberg and in Lausanne. He made the mistake of returning to France, and became a victim of the St. Bartholomew's Day Massacre (1572). Ramus's work led to a reorganization of knowledge through advances in pedagogy, rhetoric, and logic.

\section{RELATED SCHOLARS}

Beyond those who taught at the Royal College, one other important person is related to the College. He probably did not occupy an official position, but was its instigator. This scholar is counted to establish all figures but Figure 3.

Guillaume Budé (Paris 1467 - Paris 1540) held several highly ranked positions in the administration. As a humanist, he contributed to the renewal of the study of Roman law by integrating historical aspects, and contributed greatly to the study of Greek literature in France. He convinced the King not to forbid the newly invented printing press and led him to found the Royal College next to the university, to develop freely the new humanistic research program.

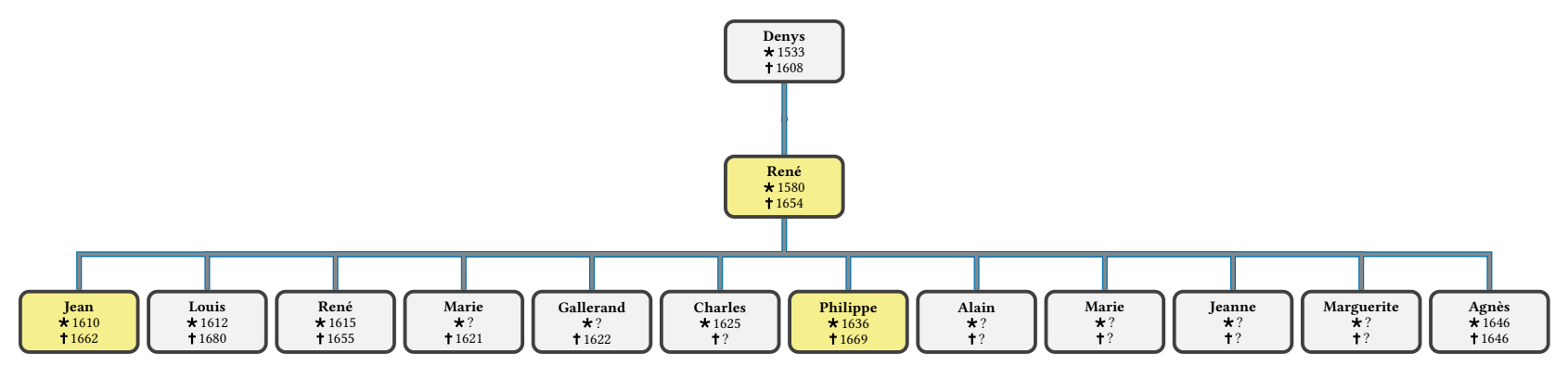

Figure 4: The Chartier family. Professors at the Royal College in yellow squares

\section{FAMILIES OF SCHOLARS}

We counted 13 father-son pairs among the professors at the Royal College. Figure 4 shows a part of the genealogical tree of the Chartier family, who contributed three professors in medicine to the Royal College. The father, René, has 250 publications mentioned on Worldcat, while his sons have 23 (Jean) and 0 (Philippe). This might indicate some degree of favoritism in the appointments (De la Croix and Goñi 2020). 


\section{WHO'S WHO ON THE MOON}

Another way to measure the notability of individuals is to look for signs of recognition such as street names, ... and lunar crater names. The following five professors received this honor (with first year at the Royal College): Joseph-Nicolas Delisle (1718), Pierre Gassendi (1643), Joseph Jérôme Lefrançois de Lalande (1762), Pierre-Charles Le Monnier (1746), and Joannes Stadius (1576).

\section{APPENDIX}

The individual human capital index $q_{i}$ of an individual $i$ is given by:

$$
\begin{aligned}
q_{i}= & -1.76+0.43 \ln (\mathrm{nb} . \text { characters of the longest Wikipedia page }) \\
& +0.40 \ln (\mathrm{nb} . \text { wikipedia pages in different languages })+0.47 \ln (\text { nb. works in Worldcat }) \\
& +0.46 \ln (\mathrm{nb} \text {. publication languages in Worldcat })+0.47 \ln (\mathrm{nb} \text {. library holdings in Worldcat })
\end{aligned}
$$

We assume that having no Wikipedia page is similar to having one page with a length of 60 characters and that having no Worldcat page is similar to having a page with one work in one language held by one library. The constant -1.76 normalizes $q_{i}$ at 0 when there is neither a Wikipedia page, nor a Worldcat page. The weights $(0.43,0.40$, etc) are obtained from the first principal component of the five indicators (De la Croix et al. 2020). The notability $Q$ of a university aggregates the $q$ of the top 5 persons who were active in the preceding 25 years using the following formula:

$$
Q=\sqrt{\sum_{i=1}^{5} \frac{1}{5}\left(\frac{q_{i}}{s_{i}}\right)^{2}}
$$

where $s_{i}$ is the number of universities in which $i$ had an appointment.

\section{ACKNOWLEDGMENTS}

This project has received funding from the European Research Council (ERC) under the European Union's Horizon 2020 research and innovation programme under grant agreement No 883033 "Did elite human capital trigger the rise of the West? Insights from a new database of European scholars."

First version December 3, 2020. Updated September 6, 2021

\section{REFERENCES}

Applebaum, Wilbur. 2003. Encyclopedia of the scientific revolution: from Copernicus to Newton. New York: Routledge.

Collège de France. 2007. "Liste des professeurs depuis la fondation du Collège de France en 1530." Paris.

Compère, Marie-Madeleine. 2002. “Collège royal." In Les collèges français 16e-18e siècle Répertoire 3 - Paris, 407-413. Paris: Institut national de recherche pédagogique.

De la Croix, David, Frédéric Docquier, Alice Fabre, and Robert Stelter. 2020. "The Academic Market and the Rise of Universities in Medieval and Early Modern Europe (1000-1800)." CEPR Discussion Paper 14509.

De la Croix, David, and Marc Goñi. 2020. "Nepotism vs. Intergenerational Transmission of Human Capital in Academia (1088-1800).” CEPR Discussion Paper No. 15159.

Guénée, Simone. 1981. Bibliographie des universités françaises des origines à la Révolution, Généralités-Université de Paris, 1981. Paris: Picard.

Michaud, Joseph-François. 1811. Biographie universelle ancienne et moderne, 45 vols. Paris: Bureau de la Biographie Universelle. 